\title{
Joanna Wyszkowska-Kuna
}

Uniwersytet Łódzki

e-mail: jkuna@uni.lodz.pl

\section{WERYFIKACJA CECH CHARAKTERYZUJĄCYCH DZIAŁALNOŚĆ INNOWACYJNĄ I INNOWACJE W FIRMACH USEUGOWYCH NA PODSTAWIE WYNIKÓW BADAŃ COMMUNITY INNOVATION SURVEY \\ VERIFICATION OF CHARACTERISTICS OF INNOVATION ACTIVITY AND INNOVATIONS IN SERVICE COMPANIES BASED ON THE RESULTS OF THE COMMUNITY INNOVATION SURVEY}

DOI: $10.15611 / \mathrm{e} 21.2015 .1 .06$

JEL Classification: O31, L80

Streszczenie: Celem artykułu jest zbadanie cech charakteryzujących działalność innowacyjną i innowacje w firmach usługowych na podstawie wyników badań Community Innovation Survey oraz próba oceny tych badań pod kątem ich skuteczności w ujmowaniu działalności innowacyjnej i innowacji w firmach usługowych. W pierwszej części tekstu wskazano cechy usług, które determinują charakter działalności innowacyjnej i modelu innowacji w firmach usługowych. W dalszej jego części podjęto ich empiryczną weryfikację na podstawie wyników badań CIS dla wszystkich krajów UE. Uwzględnienie wszystkich krajów UE daje dużą liczbę obserwacji, a należy zauważyć, iż dotychczasowe badania w tym obszarze prowadzone były na podstawie danych dla pojedynczych krajów. Metodą badawczą jest porównanie działalności innowacyjnej firm przemysłowych i firm usługowych w krajach UE, co pokazuje ewentualne różnice w charakterze działalności innowacyjnej firm z obydwu sektorów. Dzięki temu można odpowiedzieć na pytanie, czy działalność innowacyjną firm usługowych można badać za pomocą tych samych narzędzi, które stosowane są w firmach przemysłowych (podejście asymilacyjne), czy też należy opracować nowe metody pomiaru działalności innowacyjnej - (a) specyficzne dla firm usługowych (podejście wyróżniające), czy (b) odnoszące się jednocześnie do firm z obydwu sektorów (podejście integracyjne). W artykule pozytywnie zweryfikowano wszystkie cechy, z wyjątkiem interaktywnego charakteru działalności innowacyjnej firm usługowych. Należy przy tym zwrócić uwagę na dane pochodzące z dwóch ostatnich rund badań, które pokazują, iż innowacje nietechnologiczne są równie ważne w firmach przemysłowych, jak i w firmach usługowych, a obydwa typy innowacji na ogół się uzupełniają. Wynika stąd ciekawy wniosek, że nie można dokonać prostego rozróżnienia na innowacje technologiczne w firmach przemysłowych i na innowacje nietechnologiczne w firmach usługowych, a badania nad działalnością innowacyjną powinny się raczej opierać na podejściu integracyjnym. Niestety, dominacja podejścia asymilacyjnego w badaniu CIS, 
sprawia, iż działalność innowacyjna firm usługowych wciąż nie jest dokładnie zbadana. Dlatego też, mimo pozytywnych zmian w jakości danych, które widoczne są przy porównaniu wyników najnowszych i najstarszych rund CIS, konieczne są dalsze zmiany w tym obszarze. Propozycje takich zmian zostały przedstawione w artykule.

Słowa kluczowe: działalność innowacyjna, innowacje w firmach usługowych, usługi.

Summary: The purpose of this article is the empirical verification of characteristics of innovation activity and innovation in service companies based on the results of the Community Innovation Survey. In the first part of the study the characteristics of services that determine the nature of innovation activity and innovation model in service companies are indicated. In the following part the empirical verification of these features, based on the results of the CIS for all EU countries, is carried out. Including into the study all EU countries gives a large number of observations, and it should be noted that the previous studies in this area have been conducted based on the data for the individual countries. The research method is to compare the innovative activities of industrial and service companies in the EU countries, which shows the possible differences in the nature of innovation activities of companies from both sectors. This allows to answer the question whether the innovative activities of service companies can be studied using the same tools that are used in industrial companies (assimilation approach) or to develop new methods for measuring innovative activity - (a) specific to service companies (demarcation approach) or (b) relating both to companies from both sectors (integration approach). In the article all the characteristics of innovation activity in service companies are positively verified. The exception is an interactive nature of innovation activities in service companies. It is important to pay attention to the data from the last two CIS rounds, from which we can find out that non-technological innovations are equally important in industrial companies, as well as in service companies, and both types of innovation are generally complementary to each other. It follows an interesting conclusion that it is impossible to make a simple distinction between technological innovation in industrial companies and non-technological one in service companies, and research on innovation activities should rather be based on an integration approach. Unfortunately, the dominance of assimilation approach in CIS makes innovative activities of service companies are still not thoroughly examined and fully recognized. Therefore, despite the positive changes in the quality of the data, which can be seen when comparing the results of the latest and possibly the oldest CIS rounds, further changes are necessary in this area. Proposals for such changes are indicated by the author.

Keywords: services, innovation activity, innovations in service firms.

\section{Wstęp}

Działalność innowacyjna i innowacje ${ }^{1}$ stanowią obecnie podstawę rozwoju gospodarczego. Jednakże, mimo dominującej roli sektora usług we współczesnych go-

${ }^{1} \mathrm{~W}$ literaturze przedmiotu używane są określenia ,innowacje w usługach” (innovation in services) i „,innowacje usługowe” (service innovation). Obydwa oznaczają innowacje w produktach oraz procesach usługowych i na ogół odnoszą się do innowacji w firmach/sektorach usługowych (dlatego też często są używane zamiennie). Jednakże wiele firm przemysłowych wykonuje obecnie różne funkcje usługowe i mogą one wprowadzać innowacje w produktach i procesach usługowych. Dlatego określe- 
spodarkach, są one utożsamiane głównie z przemysłem. W rezultacie działalność innowacyjna i innowacje w firmach usługowych pozostają słabo zbadane.

Działalność innowacyjna i innowacje w firmach usługowych są zdeterminowane przez cechy charakteryzujące usługi. Ze względu na ogromną różnorodność działalności usługowych trudno formułować jakiekolwiek uogólnienia na temat tych cech, a w konsekwencji również na temat natury innowacji w usługach, gdyż w każdym przypadku znajdziemy różne odstępstwa [Tether, Hipp, Miles 2001; Miles 2005]². Jednakże można wskazać pewien zestaw cech odróżniających produkty usługowe od przemysłowych, co ma wpływ na charakter działalności innowacyjnej i innowacji w firmach usługowych [Sirilli, Evangelista 1998; Hipp, Tether, Miles 2000; Tether 2001; Gallouj 2002; Miles 2005].

W literaturze przedmiotu podejmowano już problematykę empirycznej weryfikacji cech charakteryzujących innowacje w usługach, jednakże analizowano je w odniesieniu do jednego kraju lub ich niewielkiej grupy krajów ([Sirilli, Evangelista, 1998; Tether, 2001; Tether, 2002; Tether, 2004; Camacho, Rodriguez 2005] - Hiszpania, [Hipp, Grupp 2005] - German innovation survey, [Bloch 2007] - kraje nordyckie, [Gotsch i in. 2010] - Knowledge Intensive Business Services - KIBS). Ponadto analizy te prowadzone były na ogół na podstawie wyników pierwszych badań nad działalnością innowacyjną (krajowych, CIS lub Innobarometer), kiedy specyfika działalności innowacyjnej w firmach usługowych była jeszcze słabo zbadana.

Celem niniejszego opracowania jest analiza cech charakteryzujących działalność innowacyjną i innowacje $\mathrm{w}$ firmach usługowych na podstawie danych pochodzących ze wszystkich krajów UE. Daje to dużą liczbę obserwacji, a ponadto pozwala wskazać ewentualne różnice między poszczególnymi krajami, w tym w szczególności między krajami starej UE i krajami przyjętymi do UE w latach 2004 i 2007. Co prawda, Kanerva, Hollanders i Arundel [2006] zwracają uwagę na trudności dotyczące możliwości porównywania efektów działalności innowacyjnej w sektorze usługowym między krajami, szczególnie jeśli znajdują się one na różnym poziomie rozwoju gospodarczego. Jednakże w artykule uwaga koncentruje się na cechach działalności innowacyjnej i innowacji w usługach, dlatego trudności te mogą się odnosić głównie do punktu 3.2. Porównanie wyników najnowszych i najstarszych rund badań CIS pozwala $\mathrm{z}$ kolei zbadać zmiany $\mathrm{w}$ jakości danych dotyczących działalności innowacyjnej firm usługowych.

\footnotetext{
nie ,innowacje usługowe” powinno być rozumiane szerzej - jako obejmujące innowacje w produktach i procesach usługowych wprowadzanych przez firmy zarówno usługowe, jak i przez firmy przemysłowe [Miles 2010]. W niniejszym artykule przedmiotem analizy jest charakterystyka działalności innowacyjnej w firmach usługowych, w związku z czym używane są określenia „innowacje w usługach” lub „innowacje w firmach usługowych”.

${ }^{2}$ Dlatego sugerowane są raczej analizy sektorowe [Tether, Hipp, Miles 2001; Howells 2010].
} 


\section{Cechy charakteryzujące działalność innowacyjną i innowacje w firmach usługowych}

Z punktu widzenia badań nad innowacjami i działalnością innowacyjną firm usługowych dwie cechy usług wydają się najistotniejsze [Sirilli, Evangelista 1998; Gallouj, 2002a; Tether 2004; Hipp, Grupp 2005; Miles 2010]. Pierwsza związana jest z niemożnością oddzielenia czasu oraz miejsca produkcji i konsumpcji większości usług, ponieważ powstają one $\mathrm{w}$ bezpośrednim kontakcie między dostawcą a odbiorcą usługi. W rezultacie w różnych fazach działalności usługowej (np. projektowanie, produkcja, dostarczanie, konsumpcja), a w konsekwencji również w procesach innowacyjnych, kluczową rolę odgrywają relacje między usługodawcą a klientem ${ }^{3}$ [Miles i in. 1995; Gallouj, Weinstein 1997; Gallouj 2002b; Gallouj, Weinstein 1997; Miles 2005].

Drugą cechą usług jest niematerialność (intangibility) produktu usługowego [Miles i in. 1995] $]^{4}$. Ma ona określone konsekwencje w postaci trudności z:

- Odróżnieniem produktu od procesu usługowego, a w konsekwencji innowacji produktowej od procesowej - często są one traktowane jako tożsame, ponieważ produkt usługowy to na ogół nie rezultat, lecz proces/pakiet usług/zestaw procedur/akt [Gallouj, Weinstein 1997].

- Mierzeniem innowacji o charakterze niematerialnym - takie innowacje na ogół występują w przypadku usług dostarczanych bez użycia materialnej technologii, a jedynie za pomocą kompetencji usługodawcy [Gallouj, Weinstein 1997]. Są one bardziej ulotne i dlatego trudniej je zmierzyć, a łatwiej skopiować [Hipp, Grupp 2005]. Ponadto trudniej oszacować ich ekonomiczne efekty (np. wpływ na sprzedaż lub produktywność), przekonać konsumentów, że usługa jest wystarczająco nowa, co uzasadnia jej wyższą cenę, oraz określić granicę między różnicowaniem produktu a prawdziwą innowacją.

${ }^{3}$ Obecnie mamy do czynienia z rosnącym znaczeniem relacji między producentem a konsumentem w całym ekonomicznym systemie, ponieważ wszystkie produkty postrzegane są jako pewna kombinacja towarów i usług. Ponadto widoczny jest wzrost aktywności użytkowników w procesie innowacyjnym, którzy w coraz większym stopniu są zdolni do własnej innowacyjności, co pociąga za sobą odejście od procesów innowacyjnych, skoncentrowanych na przetwórcy, w kierunku procesów skoncentrowanych na użytkowniku [Von Hippel 1988; 2005].

${ }^{4}$ Jak dowodzi Hill [1999], niematerialność jest błędnie postrzegana jako cecha charakteryzującą usługi. Jest to cecha grupy produktów, określanych jako „wartości niematerialne i prawne” (intangibles), czyli oryginalne dzieła stworzone przez autorów, kompozytorów, naukowców, architektów, inżynierów, projektantów, twórców programów komputerowych, filmów itp. - są one niematerialne, ponieważ nie mają wymiaru fizycznego i muszą być zapisane na fizycznych mediach, takich jak: papier, taśma, płyta, pendrive itp., lub mogą być nadane/przesłane drogą elektroniczną. Hill wskazuje na dwie inne cechy kluczowe dla charakterystyki usług: (1) usługi nie mogą być produkowane bez wcześniejszego porozumienia, kooperacji i ewentualnie aktywnego udziału konsumującej jednostki (jednostek); (2) wytworzone produkty nie są oddzielnymi jednostkami, istniejącymi niezależnie od producentów lub konsumentów (ze względu na tę cechę są postrzegane jako niematerialne produkty). 
- Identyfikowaniem i mierzeniem innowacji typu „ciągła zmiana”, które częściej występują w firmach usługowych ${ }^{5}$. Zmiany tu są małe, ale ciągłe, a innowację stanowią dopiero wtedy, gdy postrzega się je jako całość - w efekcie są one jednak często trudno zauważalne ${ }^{6}$. Ponadto bieżące wykonanie usługi nie stanowi zapisu jej poprzedniego wykonania, w związku z czym nie można porównać różnych wersji produktu w celu oceny istotności zmian.

Z badań wynika ponadto, iż w działalności innowacyjnej firm usługowych kluczową rolę odgrywają zmiany organizacyjne ${ }^{7}$ oraz inwestycje w technologie informacyjno-komunikacyjne (ICT) ${ }^{8} \mathrm{i}$ w zasoby ludzkie. W związku z powyższym postulowano rozszerzenie koncepcji innowacji o zmiany organizacyjne [OECD 1997; Hipp, Tether, Miles 2000; Tether i in. 2002; Gallouj 2002a; Hipp, Grupp 2005], co też się stało wraz z wprowadzeniem rozszerzonej definicji innowacji [OECD/Eurostat 2005; Eurostat 2008; OECD 2011]. Postulowano także włączenie w definicję innowacji i wydatków na działalność innowacyjną wydatków ponoszonych na wytwarzanie i rozprzestrzenianie ICT [Hackett 1990; Sirilli, Evangelista 1998; Antonelli 1998; 1999; Hipp, Tether, Miles 2000; Howells 2000; Hipp, Grupp 2005] oraz wydatków związanych z inwestycjami w szkolenia [Tether i in. 2002; Leiponen 2006] - zagadnienie to jest szerzej omawiane w punktach 3.3 i 3.4 .

\section{Weryfikacja cech charakteryzujących działalność innowacyjną i innowacje w firmach usługowych}

W tym punkcie podjęto empiryczną weryfikację cech charakteryzujących działalność innowacyjną i innowacje w firmach usługowych. W tym celu wykorzystano wyniki ostatniego badania CIS-7 (2010 r.), porównując je z wynikami możliwie naj-

\footnotetext{
${ }^{5}$ Szczególnie jest to widoczne w firmach dostarczających niedokładnie zdefiniowane i niereprodukowane produkty usługowe [Tether 2004; 2005; Hertog, Miles 1995; Voss i in. 1992; Scarbrough, Lannon 1989; Sundbo 1997].

${ }^{6}$ Dla produktów dobrze zdefiniowanych (produkty przemysłowe i niektóre usługi) charakterystyczny jest model innowacji typu „krokowa zmiana”, w którym usprawnienia (np. nowsza wersja produktu) mają postać serii zmian krokowych, pojawiających się między okresami funkcjonowania niezmienionego produktu, a wzięte jako całość tworzą innowację typu „schody” [Tether 2005].

${ }^{7}$ Zmiany organizacyjne $\mathrm{w}$ usługach mogą być powiązane $\mathrm{z}$ innowacjami technologicznymi (np. wprowadzenie bankomatów czy bankowości domowej pociągnęło za sobą znaczące zmiany organizacyjne w działalności bankowej) lub niezależne od nich (np. innowacje w zakresie zarządzania - standaryzacja niektórych usług czy systemy jakości w usługach) [Hertog, Miles 1995]. Możliwe są tu także problemy z identyfikowaniem oraz ze stopniowaniem tych zmian, jak również problemy z odróżnieniem innowacji organizacyjnych od procesowych [Hipp, Tether, Miles 2000; Tether 2004].

${ }^{8}$ Jest to efektem wysokiej zawartości informacji w produktach i procesach usługowych (głównie w sektorze Knowledge Intensive Services - KIS, a w szczególności w niektórych KIBS [Gotsch i in. 2010], a także niematerialnego charakteru produktów usługowych.
} 
wcześniejszego badania, tj. na ogół CIS-4 (2004 r.) $)^{9}$, z odniesieniem również do CIS-6 (2008 r. $)^{10}$.

\subsection{Interaktywny charakter działalności innowacyjnej w firmach usługowych}

Do zbadania, czy proces innowacyjny w firmach usługowych charakteryzuje się większą interaktywnością niż proces innowacyjny w firmach przemysłowych, wykorzystać można wyniki badania CIS na temat współpracy badanych firm z różnymi rodzajami podmiotów (Innovation co-operation during 2002-2004 oraz Types of co-operation partner for product and process innovation.

O interaktywnym modelu innowacji świadczy duży stopień zaangażowania klienta $\mathrm{w}$ proces innowacyjny. Jak wynika $\mathrm{z}$ danych przedstawionych $\mathrm{w}$ tab. 1 , w większości krajów odsetek firm wskazujących klientów lub konsumentów (C) jako najbardziej wartościowych partnerów w procesie innowacyjnym plasował się na drugim miejscu wśród firm zarówno usługowych, jak i przemysłowych - na ogół po dostawcach sprzętu, materiałów, komponentów i oprogramowania (B), a przed innymi przedsiębiorstwami z tej samej grupy przedsiębiorstw (A). Nie zaobserwowano tu istotnych różnic między krajami starej UE i krajami nowo przyjętymi do UE - jedynie w kilku krajach nowo przyjętych trochę wyższy był odsetek przedsiębiorstw wskazujących na partnerów z kategorii B i C. Jednakże, co ciekawe, w większości krajów na współpracę z klientami lub konsumentami częściej wskazywały firmy przemysłowe niż usługowe - w latach 2002-2004 sytuacja taka miała miejsce w 11 krajach na 14, w latach 2006-2008 - w 16 państwach, a w $2010 \mathrm{r}$. - w 19. Dane te nie potwierdzają zatem, iż interaktywny model innowacji jest charakterystyczny dla firm usługowych.

Tabela 1. Odsetek przedsiębiorstw wskazujących współpracę z danym partnerem (partnerami) jako najbardziej wartościową w procesie innowacyjnym w stosunku do przedsiębiorstw, które wprowadziły innowacje technologiczne w latach 2002-2004 oraz 2008-2010 (wartości w \%)

\begin{tabular}{|c|c|c|c|c|c|c|c|c|c|c|c|c|c|c|c|}
\hline \multirow{2}{*}{ Wyszczególnienie } & & \multicolumn{2}{|c|}{ A } & \multicolumn{2}{|c|}{ B } & \multicolumn{2}{|c|}{$\mathrm{C}$} & \multicolumn{2}{|c|}{$\mathrm{D}$} & \multicolumn{2}{|c|}{$\mathrm{E}$} & \multicolumn{2}{|c|}{$\mathrm{F}$} & \multicolumn{2}{|c|}{ G } \\
\hline & & $\mathrm{P}$ & $\mathrm{U}$ & $\mathrm{P}$ & $\mathrm{U}$ & $\mathrm{P}$ & $\mathrm{U}$ & $\mathrm{P}$ & $\mathrm{U}$ & $\mathrm{P}$ & $\mathrm{U}$ & $\mathrm{P}$ & $\mathrm{U}$ & $\mathrm{P}$ & $\mathrm{U}$ \\
\hline 1 & 2 & 3 & 4 & 5 & 6 & 7 & 8 & 9 & 10 & 11 & 12 & 13 & 14 & 15 & 16 \\
\hline \multirow[t]{2}{*}{ Belgia } & 2004 & 9 & 10 & 12 & 11 & 9 & 8 & 2 & 1 & 1 & 4 & 3 & 1 & 1 & 1 \\
\hline & 2010 & 6 & 6 & 15 & 11 & 5 & 5 & 1 & 2 & 4 & 2 & 5 & 4 & 2 & 3 \\
\hline Bułgaria & 2010 & 3 & 7 & 7 & 11 & 5 & 7 & 1 & 3 & 2 & 2 & 1 & 2 & 0,3 & 1 \\
\hline \multirow[t]{2}{*}{ Czechy } & 2004 & 6 & 6 & 12 & 15 & 14 & 8 & 2 & 2 & 3 & 4 & 2 & 2 & 1 & 1 \\
\hline & 2010 & 6 & 10 & 11 & 6 & 10 & 8 & 1 & 2 & 3 & 1 & 4 & 4 & 1 & 1 \\
\hline Niemcy & 2010 & 4 & 2 & 6 & 3 & 5 & 3 & 1 & 1 & 3 & 4 & 8 & 5 & 3 & 1 \\
\hline
\end{tabular}

${ }^{9}$ Badanie CIS-1 było pilotażowe i nie obejmowało sektora usług. Wyniki badania CIS-2 i na ogół również CIS-3 nie są porównywalne z wynikami kolejnych rund badań, a poza tym są mało kompletne. Dlatego w większości przypadków wykorzystywano wyniki badania CIS-4.

${ }^{10}$ Wyniki kolejnych rund badania CIS dostępne są na stronie Eurostatu. 
Weryfikacja cech charakteryzujących działalność innowacyjną i innowacje w firmach...

\begin{tabular}{|c|c|c|c|c|c|c|c|c|c|c|c|c|c|c|c|}
\hline 1 & 2 & 3 & 4 & 5 & 6 & 7 & 8 & 9 & 10 & 11 & 12 & 13 & 14 & 15 & 16 \\
\hline Estonia & 2010 & 13 & 14 & 10 & 14 & 11 & 7 & 3 & 1 & 4 & 3 & 2 & 1 & 1 & 1 \\
\hline \multirow[t]{2}{*}{ Hiszpania } & 2004 & 2 & 2 & 6 & 6 & 2 & 1 & 2 & 1 & 2 & 1 & 2 & 1 & 3 & 1 \\
\hline & 2010 & 3 & 2 & 5 & 6 & 2 & 2 & 1 & 2 & 2 & 2 & 3 & 3 & 5 & 2 \\
\hline Włochy & 2010 & 1 & 2 & 2 & 4 & 2 & 2 & 1 & 3 & 4 & 2 & 2 & 2 & 0,2 & 1 \\
\hline \multirow[t]{2}{*}{ Cypr } & 2004 & 2 & 4 & 13 & 18 & 2 & 1 & 9 & 8 & 9 & 7 & 1 & - & 1 & - \\
\hline & 2010 & 2 & 8 & 18 & 29 & 23 & 18 & 3 & 2 & 10 & 9 & 1 & 1 & 1 & 0,4 \\
\hline Łotwa & 2010 & 7 & 9 & 8 & 7 & 6 & 8 & 1 & 2 & 4 & 4 & 1 & 2 & 0,3 & 1 \\
\hline \multirow[t]{2}{*}{ Litwa } & 2004 & 8 & 9 & 23 & 25 & 8 & 15 & 1 & 5 & 6 & 4 & 1 & 4 & 1 & 2 \\
\hline & 2010 & 6 & 10 & 17 & 23 & 6 & 10 & 1 & 1 & 3 & 2 & 1 & 3 & 4 & 1 \\
\hline \multirow[t]{2}{*}{ Luksemburg } & 2004 & 8 & 9 & 9 & 11 & 11 & 4 & 2 & 1 & 3 & 1 & 1 & 1 & - & - \\
\hline & 2010 & 7 & 9 & 11 & 11 & 9 & 4 & 1 & 4 & 4 & 1 & 3 & 0,2 & 3 & 1 \\
\hline \multirow[t]{2}{*}{ Węgry } & 2004 & 6 & 5 & 13 & 15 & 8 & 7 & 2 & 4 & 3 & 3 & 4 & 5 & 1 & 1 \\
\hline & 2010 & 8 & 5 & 9 & 14 & 7 & 5 & 4 & 4 & 6 & 7 & 10 & 7 & 1 & 2 \\
\hline \multirow[t]{2}{*}{ Malta } & 2004 & 18 & 10 & 10 & 14 & 8 & 14 & - & 5 & 4 & 5 & - & - & - & - \\
\hline & 2010 & 9 & 3 & 4 & 6 & 3 & 3 & - & 2 & 2 & 1 & 2 & 1 & - & 1 \\
\hline \multirow[t]{2}{*}{ Holandia } & 2004 & 9 & 9 & 17 & 12 & 10 & 7 & 1 & 2 & 3 & 2 & 2 & 1 & 2 & 2 \\
\hline & 2010 & 6 & 2 & 16 & 14 & 6 & 3 & 2 & 3 & 4 & 3 & 3 & 2 & 1 & 1 \\
\hline Austria & 2010 & 10 & 14 & 14 & 13 & 9 & 7 & 2 & 5 & 5 & 5 & 10 & 6 & 1 & 1 \\
\hline \multirow[t]{2}{*}{ Polska } & 2004 & 6 & 12 & 17 & 16 & 9 & 4 & 2 & 2 & 3 & 2 & 2 & 1 & 5 & 5 \\
\hline & 2010 & 7 & 8 & 10 & 13 & 5 & 4 & 1 & 2 & 3 & 3 & 4 & 2 & 4 & 1 \\
\hline \multirow[t]{2}{*}{ Portugalia } & 2004 & 2 & 4 & 4 & 6 & 5 & 4 & 1 & 1 & 2 & 3 & 3 & 2 & 1 & 1 \\
\hline & 2010 & 3 & 4 & 6 & 7 & 5 & 5 & 0,4 & 1 & 2 & 1 & 2 & 2 & 1 & 1 \\
\hline \multirow[t]{2}{*}{ Rumunia } & 2004 & 2 & 2 & 5 & 7 & 3 & 4 & 1 & 1 & 1 & 1 & 1 & 2 & 1 & 2 \\
\hline & 2010 & 1 & 1 & 4 & 11 & 5 & 4 & 1 & 1 & 1 & 2 & 2 & 1 & 0,4 & - \\
\hline Słowenia & 2010 & 14 & 11 & 29 & 25 & 25 & 24 & 11 & 14 & 22 & 18 & 23 & 18 & 15 & 12 \\
\hline \multirow[t]{2}{*}{ Słowacja } & 2004 & 6 & 5 & 17 & 10 & 12 & 11 & 1 & 4 & 1 & 5 & 1 & 1 & 1 & 1 \\
\hline & 2010 & 9 & 7 & 12 & 13 & 7 & 12 & 3 & 1 & 1 & 2 & 1 & 1 & 0,2 & 1 \\
\hline \multirow[t]{2}{*}{ Szwecja } & 2004 & 7 & 5 & 18 & 16 & 14 & 10 & 1 & 1 & 4 & 3 & 3 & 2 & 1 & 1 \\
\hline & 2010 & 9 & 7 & 14 & 13 & 11 & 7 & 2 & 2 & 6 & 4 & 3 & 3 & 1 & 0,2 \\
\hline
\end{tabular}

* A - inne przedsiębiorstwa w ramach danej grupy przedsiębiorstw; B - dostawcy sprzętu, materiałów, komponentów i oprogramowania; $\mathrm{C}$ - klienci/konsumenci; D - konkurenci lub inne firmy z tego samego sektora; E - konsultanci, komercyjne laboratoria lub prywatne instytuty B+R; F - uniwersytety lub inne instytucje wyższej edukacji; $\mathrm{G}$ - rząd lub publiczne instytuty badawcze; $\mathrm{P}$ - przemysł (B-E według NACE Rev.2); U - usługi gospodarki biznesowej (G-N według NACE Rev.2). W przypadku Bułgarii (dla A, B i E), Niemiec, Estonii, Luksemburga, Austrii dane odnoszą się do usług stanowiących rdzeń działalności innowacyjnej (G46, H, J58, J61, J62, J63, K i M71).

Źródło: [Eurostat, Results of the fourth Community Innovation survey (CIS4) (inn_cis4), Innovation co-operation during 2002-2004 (inn_cis4_coop), Results of the Community Innovation survey 2010, Types of co-operation partner for product and process innovation (Inn_cis7_coop)]. 
Należy także zauważyć, iż w badaniu CIS dane na temat partnerów, z którymi firma współpracuje w procesie innowacyjnym, odnoszą się jedynie do firm wprowadzających innowacje technologiczne, tj. produktowe i procesowe. Taki zakres badania pomija firmy, które wprowadziły tylko innowacje nietechnologiczne, a odsetek takich firm jest wyższy wśród firm usługowych niż przemysłowych. Dlatego możliwość weryfikacji tej cechy jest wciąż ograniczona.

Jeśli chodzi o pozostałe kategorie partnerów, to w większości krajów firmy usługowe częściej wskazywały na partnerów z kategorii D, E i G, natomiast przedsiębiorstwa przemysłowe - na partnerów z kategorii F. W przypadku ostatniej kategorii w większości krajów odsetek firm w obydwu sektorach kształtował się na podobnym poziomie. Jednakże w latach 2008-2010, podobnie jak w okresie 2006-2008, partnerzy z kategorii D-G byli rzadko wskazywani jako najbardziej wartościowi w procesie innowacyjnym.

\subsection{Trudności z oszacowaniem ekonomicznych efektów działalności innowacyjnej w firmach usługowych}

Zgodnie z zaleceniami podręcznika Oslo Manual wskaźnikiem do oceny ekonomicznych efektów działalności innowacyjnej przedsiębiorstwa jest udział w badanym roku przychodów ze sprzedaży produktów nowych i istotnie ulepszonych, wprowadzonych na rynek $\mathrm{w}$ ostatnich trzech latach w wartości przychodów ogółem. Wskaźnik ten stanowi ważną informację o wpływie innowacji produktowych na ogólną strukturę przychodów i poziom innowacyjności przedsiębiorstwa [GUS, Urząd Statystyczny w Szczecinie 2010].

Jak pokazują dane przedstawione w tab. 2 i na rys. 1, w UE (27) w sektorze usług obrót $\mathrm{z}$ innowacji jako procent obrotu ogółem był w całym analizowanym okresie średnio około dwukrotnie niższy niż w sektorze przemysłowym (w Polsce 3-krotnie w latach 2004 i 2010, poza tym też 2-krotnie). Co prawda, dane dotyczące innowacyjności przedsiębiorstw pokazują niższy poziom innowacyjności firm usługowych niż przemysłowych, jednakże różnica w poziomie innowacyjności nie jest tak duża jak różnica w przypadku obrotów z innowacji - odsetek innowacyjnych przedsiębiorstw (na podstawie nowej, rozszerzonej definicji innowacji) w sektorze usług jest tylko o kilka punktów procentowych niższy niż odsetek innowacyjnych przedsiębiorstw $\mathrm{w}$ sektorze przemysłowym. Tak duża różnica $\mathrm{w}$ wielkości obrotów $\mathrm{z}$ innowacji w firmach przemysłowych i usługowych jest prawdopodobnie efektem tego, iż trudniej oszacować efekt działalności innowacyjnej w firmach usługowych ${ }^{11}$.

${ }^{11}$ Dlatego też, jak zauważają Gago i Rubalcaba [2007], nie jest to odpowiednia metoda, pozwalająca ująć w pełni ekonomiczne efekty innowacji usługowych. Również Hipp, Tether, Miles [2000], badając innowacyjność niemieckich firm, znaleźli słaby związek między innowacją a wzrostem sprzedaży w firmach usługowych. 
Weryfikacja cech charakteryzujących działalność innowacyjną i innowacje w firmach...

Tabela 2. Obrót z innowacji jako procent obrotu ogółem w przemyśle i usługach w latach 2004-2010

\begin{tabular}{|c|c|c|c|c|c|c|c|c|}
\hline \multirow{2}{*}{ Wyszczególnienie } & \multicolumn{4}{|c|}{ Przemysł } & \multicolumn{4}{|c|}{ Usługi } \\
\hline & 2004 & 2006 & 2008 & 2010 & 2004 & 2006 & 2008 & 2010 \\
\hline EU (27) & 17 & 19 & 18 & - & 10 & 9 & 9 & - \\
\hline Belgia & 17 & 12 & 11 & - & 10 & 8 & 8 & - \\
\hline Bułgaria & 11 & 14 & 19 & - & 15 & 6 & 9 & - \\
\hline Czechy & 18 & 17 & 24 & - & 11 & 10 & 11 & - \\
\hline Dania & 18 & 16 & 16 & - & 6 & 4 & 8 & - \\
\hline Niemcy & 23 & 27 & 24 & - & 12 & 12 & 11 & - \\
\hline Estonia & 14 & 12 & 12 & - & 11 & 15 & 9 & - \\
\hline Irlandia & 18 & 16 & 9 & - & 3 & 10 & 12 & - \\
\hline Grecja & 14 & 31 & - & - & 9 & 20 & - & - \\
\hline Hiszpania & 15 & 19 & 21 & - & 12 & 13 & 12 & - \\
\hline Francja & 16 & - & 17 & - & 8 & - & 10 & - \\
\hline Włochy & 12 & 10 & 12 & - & 13 & 8 & 12 & - \\
\hline Cypr & 4 & 14 & 21 & - & 6 & 12 & 15 & - \\
\hline Łotwa & 5 & 4 & 10 & - & 5 & 3 & 3 & - \\
\hline Litwa & 12 & 19 & 13 & - & 7 & 5 & 7 & - \\
\hline Luksemburg & 13 & 10 & 9 & - & 16 & 13 & 9 & - \\
\hline Węgry & 8 & 13 & 22 & - & 5 & 6 & 6 & - \\
\hline Malta & 37 & 30 & 30 & - & 4 & 28 & 5 & - \\
\hline Holandia & 13 & 14 & 11 & - & 5 & 9 & 7 & - \\
\hline Austria & 15 & 17 & 16 & - & 7 & 11 & 7 & - \\
\hline Polska & 20 & 13 & 12 & 11 & 7 & 7 & 6 & 4 \\
\hline Portugalia & 10 & 17 & 15 & - & 10 & 10 & 16 & - \\
\hline Rumunia & 20 & 22 & 20 & - & 12 & 15 & 10 & - \\
\hline Słowenia & 19 & 17 & 19 & - & 6 & 8 & 14 & - \\
\hline Słowacja & 22 & 22 & 19 & - & 14 & 8 & 10 & - \\
\hline Finlandia & 20 & 21 & 22 & - & 6 & 6 & 7 & - \\
\hline Szwecja & 16 & - & 14 & - & 10 & - & 5 & - \\
\hline W. Brytania & 17 & 17 & 13 & - & 13 & 6 & 5 & - \\
\hline
\end{tabular}

Źródło: [Eurostat, Turnover from Innovation...].

W Polsce obrót z innowacji był niższy niż w UE (27) - w przemyśle o ok. 5-6 p.p., a w usługach o ok. 2,5-4 p.p. Jedynie w 2004 r. obrót z innowacji w firmach przemysłowych w Polsce był wyższy niż w UE, ale w roku 2006 r. odnotował on spadek o 7 p.p., osiągając wartość prawie o 6 p.p. niższą niż w UE, a tendencja spadkowa, choć słabsza, utrzymała się w kolejnych latach. Natomiast w sektorze usługowym 
obrót z innowacji utrzymywał się na stabilnym poziomie, a spadek wystąpił dopiero w 2010 r. i był prawdopodobnie efektem kryzysu gospodarczego.

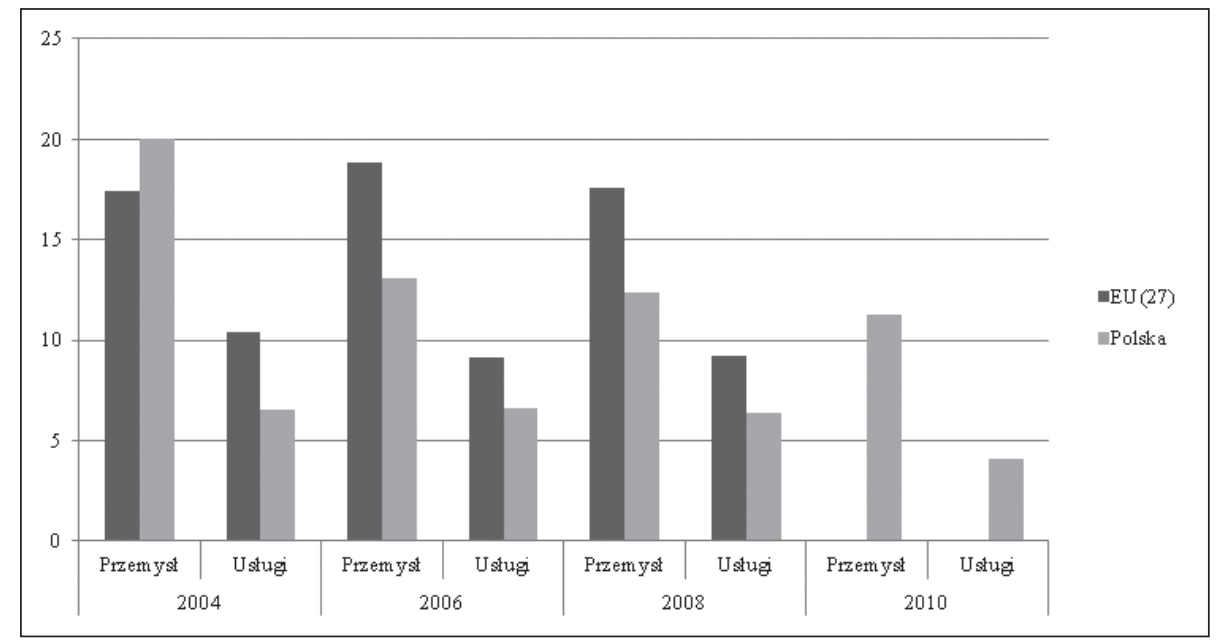

Rys. 1. Obrót z innowacji jako procent obrotu ogółem w przemyśle (P) i w usługach (U) w latach 2004-2010 w UE (27) i w Polsce

Źródło: obliczenia własne na podstawie danych z tab. 2.

\subsection{Kluczowa rola technologii informacyjno-komunikacyjnych w działalności innowacyjnej firm usługowych}

Na ICT składają się: sprzęt informatyczny i telekomunikacyjny, infrastruktura informatyczna, oprogramowanie, informatyczne systemy i struktury, metody przetwarzania informacji [Wydro, Kotowski 1998]. Nowsze definicje wskazują dodatkowo na nadawcze środki przekazu, wszystkie rodzaje przetwarzania i transmisji dźwięku i obrazu, funkcje sieciowej kontroli i monitoringu, jak również podkreślają konwergencję systemów telekomunikacyjnych, informatycznych i audiowizualnych, aby umożliwić użytkownikom dostęp, przechowywanie, transmisję i manipulowanie informacją [Porrino 2012].

Źródłem informacji na temat znaczenia ICT w procesie innowacyjnym są dane dotyczące działalności innowacyjnej i wydatków na tę działalność pochodzące z badania CIS (Innovation Activities and Expenditure) ${ }^{12}$.

${ }^{12} \mathrm{~W}$ badaniu CIS, które prowadzone jest zgodnie z zaleceniami podręcznika Oslo Manual, przedmiotem obserwacji jest tzw. budżet innowacji, tzn. wszelkie wydatki bieżące i inwestycyjne, niezależnie od źródeł finansowania, poniesione w roku sprawozdawczym na wszystkie rodzaje działalności innowacyjnej, na prace zakończone sukcesem (tzn. wdrożeniem innowacji), nie zakończone (kontynuowane) i przerwane. 
W badaniu CIS działalność innowacyjna firm mierzona jest za pomocą liczby/ odsetka firm zaangażowanych w różne rodzaje działalności innowacyjnej, a także za pomocą wydatków poniesionych na te działalności. Działalność innowacyjna definiowana jest tu jako zaangażowanie firm w następujące rodzaje działań w zakresie innowacji produktowych i procesowych [GUS, Urząd Statystyczny w Szczecinie 2012]: zakup wiedzy ze źródeł zewnętrznych; zakup oprogramowania; zakup i montaż maszyn i urządzeń technicznych, środków transportu, narzędzi, przyrządów, ruchomości, wyposażenia oraz nakłady na budynki; szkolenie personelu związane $\mathrm{z}$ działalnością innowacyjną; marketing dotyczący nowych lub istotnie ulepszonych produktów; prace badawcze i rozwojowe $(\mathrm{B}+\mathrm{R})$ - wewnętrzne i zlecone na zewnątrz; pozostałe przygotowania do wprowadzania innowacji produktowych lub procesowych; działalności designerskie mające na celu poprawę lub zmianę w wyglądzie towarów i usług (pierwszy raz w badaniu CIS-7, 2010 r.).

Niestety definicja działalności innowacyjnej nie jest spójna z definicją wydatków na działalność innowacyjną, ponieważ wydatki definiowane są w węższy i bardziej zagregowany sposób, obejmując tylko cztery kategorie: wydatki na nabycie maszyn, sprzętu i oprogramowania; wydatki na nabycie zewnętrznej wiedzy; wydatki na nabycie zewnętrznych $\mathrm{B}+\mathrm{R}$; wydatki na wewnętrzne $\mathrm{B}+\mathrm{R}$. W praktyce oznacza to trudności z oszacowaniem znaczenia wydatków na ICT w działalności innowacyjnej firm, ponieważ wydatki na zakup oprogramowania i sprzętu komputerowego włączone są do szerszej kategorii „Wydatki na nabycie maszyn, sprzętu i oprogramowania”. Co prawda, kategoria ta generowała największy procent wydatków na działalność innowacyjną, ale nie sposób określić, jaka część tych wydatków jest związana z inwestycjami w ICT.

Znaczenie ICT w działalności innowacyjnej firm usługowych można ocenić na podstawie danych dla Polski, ponieważ obejmują one wszystkie kategorie wydatków związanych z działalnością innowacyjną. W Polsce w 2010 r. całkowite wydatki na działalność innowacyjną w firmach usługowych wyniosły 10 790,3 mln zł i były ponad 2-krotnie niższe niż w firmach przemysłowych, w których wyniosły 23757 mln zł. Jednakże wydatki na zakup oprogramowania w sektorze usługowym notowały w analizowanym okresie 4-krotny wzrost udziału i dzięki temu w 2010 r. wysunęły się na drugie miejsce (za wydatkami na zakup sprzętu transportowego, maszyn i urządzeń). W przemyśle wydatki na zakup oprogramowania nie zwiększyły swojego udziału i przez cały analizowany okres plasowały się na przedostatnim miejscu. W rezultacie w 2010 r. udział tych wydatków w firmach usługowych był aż 8-krotnie wyższy niż w firmach przemysłowych i w tym obszarze miały miejsce największe dysproporcje między obydwoma sektorami ${ }^{13}$. Struktura wydatków na działalność innowacyjną w firmach przemysłowych i usługowych w Polsce w latach 2000 i 2010 przedstawiona jest na wykresie na rys. 2.

${ }^{13}$ Ponadto należy pamiętać, iż badaniu podlegały jedynie wydatki na innowacje technologiczne, co przyczynia się do zmniejszenia przewagi firm usługowych w tym obszarze. 


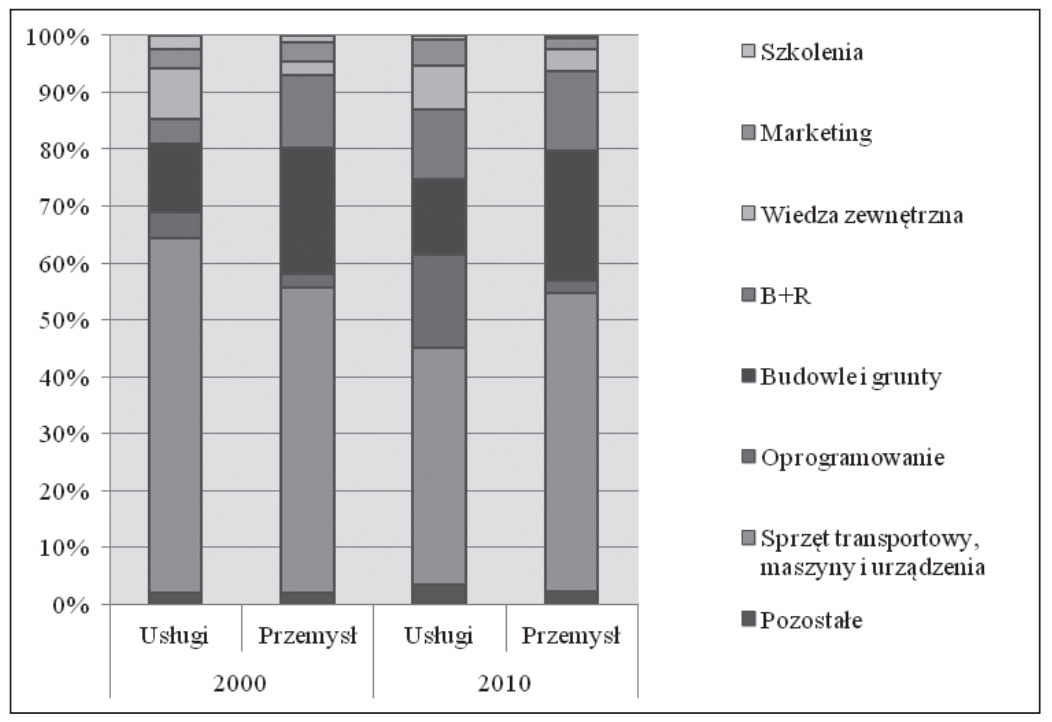

Rys. 2. Udział wydatków na poszczególne rodzaje działalności innowacyjnej w całkowitych wydatkach na działalność innowacyjną w przedsiębiorstwach przemysłowych i usługowych w Polsce w latach 2000 i 2010 (wartości w \%)

Źródło: obliczenia własne na podstawie: [GUS, Urząd Statystyczny w Szczecinie 2012, s. 75 i 79 ].

Innym źródłem informacji na temat znaczenia ICT w działalności firm usługowych i przemysłowych są dane dotyczące aktywów trwałych przedsiębiorstw. Eurostat dzieli je na następujące kategorie: (1) budowle, (2) sprzęt transportowy, (3) pozostałe maszyny i urządzenia, (4) aktywa kultywowane oraz (5) aktywa niematerialne. Do aktywów trwałych, powiązanych z ICT, zaliczyć można: w ramach kategorii czwartej - maszyny biurowe i urządzenia komputerowe oraz sprzęt radiowy, telewizyjny i komunikacyjny, a w ramach kategorii piątej - oprogramowanie.

$\mathrm{W}$ tabeli 3 przedstawiono dane pokazujące udziały aktywów trwałych powiązanych z ICT w aktywach trwałych ogółem w przetwórstwie przemysłowym i w usługach w latach 2000 i 2010 (w przypadku usług nie było podanych wartości dla całego sektora usług, lecz jedynie dla poszczególnych sektorów usługowych, więc policzono średnią dla wszystkich wyszczególnionych sektorów usług). Niestety liczba krajów dla których dostępne są dane jest niewielka. Jak wynika z tych danych, w większości krajów udział maszyn biurowych i urządzeń komputerowych wyższy był w aktywach firm usługowych niż przemysłowych, przy niewielkiej tendencji spadkowej w obydwu sektorach (w usługach w 3 krajach niewielki wzrost). Na uwagę zasługuje Dania, która w porównaniu z innymi krajami notowała bardzo wysoki udział tych aktywów (szczególnie w przemyśle - w 2000 r. był on 3-krotnie większy niż usługach, a w 2010 r. - 2,5-krotnie). W przypadku sprzętu telewizyjnego, radiowego i komunikacyjnego sytuacja była podobna, przy wzrastającej liczbie krajów z wyższym udziałem tych aktywów w usługach. 
Tabela 3. Udział aktywów trwałych powiązanych z ICT oraz aktywów niematerialnych w aktywach trwałych ogółem w przemyśle i usługach w latach 2000 i 2010 (wartości w \%)

\begin{tabular}{|c|c|c|c|c|c|c|c|c|c|c|c|c|c|c|c|c|}
\hline \multirow{3}{*}{ Wyszczególnienie } & \multicolumn{4}{|c|}{$\begin{array}{l}\text { Urz. biurowe } \\
\text { i komputerowe* }\end{array}$} & \multicolumn{4}{|c|}{$\begin{array}{l}\text { Urz. radiowe, TV } \\
\text { i komunikacyjne* }\end{array}$} & \multicolumn{4}{|c|}{$\begin{array}{l}\text { Niematerialne } \\
\text { aktywa trwałe }\end{array}$} & \multicolumn{4}{|c|}{$\begin{array}{c}\text { W tym: } \\
\text { oprogramowanie }\end{array}$} \\
\hline & $\mathrm{P}$ & $\mathrm{U}$ & $\mathrm{P}$ & $\mathrm{U}$ & $\mathrm{P}$ & $\mathrm{U}$ & $P$ & $\mathrm{U}$ & $\mathrm{P}$ & $\mathrm{U}$ & $\mathrm{P}$ & $\mathrm{U}$ & $\mathrm{P}$ & $\mathrm{U}$ & $\mathrm{P}$ & $\mathrm{U}$ \\
\hline & \multicolumn{2}{|c|}{2000} & \multicolumn{2}{|c|}{2010} & \multicolumn{2}{|c|}{2000} & \multicolumn{2}{|c|}{2010} & \multicolumn{2}{|c|}{2000} & \multicolumn{2}{|c|}{2010} & \multicolumn{2}{|c|}{2000} & \multicolumn{2}{|c|}{2010} \\
\hline Belgia & 5 & 6 & 4 & 6 & 2 & 3 & 2 & 2 & 1 & 3 & 1 & 3 & 1 & 1 & 1 & 2 \\
\hline Czechy & 7 & 2 & 6 & 2 & 4 & 1 & 3 & 1 & 1 & 3 & 1 & 3 & 1 & 2 & 1 & 2 \\
\hline Dania & 29 & 9 & 25 & 10 & 20 & 6 & 17 & 7 & 2 & 4 & 3 & 6 & 2 & 4 & 3 & 5 \\
\hline Włochy & 1 & 3 & 1 & 2 & 0,2 & 2 & 0,1 & 1 & 2 & 7 & 2 & 6 & 2 & 3 & 2 & 3 \\
\hline Litwa & 1 & 2 & 1 & 2 & 3 & 1 & 1 & 2 & 1 & 1 & 1 & 3 & 0,2 & 1 & 1 & 2 \\
\hline Węgry & - & - & - & - & - & - & - & - & 0,4 & 1 & 1 & 2 & 0,4 & 1 & 1 & 1 \\
\hline Holandia & - & - & - & - & - & - & - & - & 2 & 4 & 2 & 5 & 2 & 2 & 2 & 3 \\
\hline Austria & 1 & 1 & 1 & 1 & 0,1 & 8 & 0,3 & 6 & 3 & 4 & 3 & 5 & 3 & 3 & 3 & 4 \\
\hline Polska & - & - & - & - & - & - & - & - & 1 & 2 & 1 & 3 & - & - & - & - \\
\hline Słowenia & 1 & 2 & 1 & 2 & 0,4 & 3 & 0,2 & 2 & 1 & 2 & 2 & 3 & 1 & 1 & 1 & 2 \\
\hline Słowacja & - & - & 1 & 3 & - & - & 0,2 & 3 & - & - & 3 & 4 & - & - & 1 & 4 \\
\hline Finlandia & 1 & 1 & 1 & 1 & 1 & 1 & 2 & 1 & 2 & 5 & 5 & 7 & 2 & 4 & 5 & 6 \\
\hline
\end{tabular}

$\mathrm{P}$ - przetwórstwo przemysłowe; U - usługi (obliczenia własne - średnia dla wszystkich rodzajów działalności usługowej). * Pozostałe maszyny i wyposażenie biurowe: maszyny biurowe i urządzenia komputerowe; pozostałe maszyny i wyposażenie biurowe: wyposażenie radiowe, telewizyjne i komunikacyjne. Oprogramowanie komputerowe to część niematerialnych aktywów trwałych. Polska i Węgry - dane za 2009 r.

Źródło: obliczenia własne na podstawie danych z: [Eurostat, Cross-classification of fixed assets by industry and by non-financial fixed assets and balance sheets for non-financial assets [nama $t$ ]; Cross-classification of fixed assets by industry and by non-financial fixed asset - current prices [nama_t20_21_c]].

Jeśli chodzi natomiast o aktywa niematerialne, ich udział był wyższy w usługach niż w przemyśle we wszystkich krajach - najczęściej ok. 2-, 3-krotnie, zarówno w roku 2000, jak i w 2010, przy tendencji wzrostowej w obydwu sektorach. Największy wzrost udziału tych aktywów miał miejsce w Finlandii (w usługach i w przemyśle $+2,6$ p.p.), wysoki był również w Danii (w usługach $-+1,8$ p.p., w przemyśle $-+1,1$ p.p.) i w Polsce (w usługach $-+1,4$ p.p., w przemyśle $-+0,5$ p.p.), a w pozostałych krajach - na poziomie poniżej 1 p.p. W przypadku oprogramowania wystąpiła podobna sytuacja - we wszystkich krajach większy udział tych aktywów wyższy był w usługach niż w przemyśle - na ogół 1,5-, 2-krotnie, przy tendencji wzrostowej w obydwu sektorach. Udział aktywów niematerialnych, w tym oprogramowania, na ogół był o połowę niższy w krajach nowo przyjętych do UE. 


\subsection{Kluczowa rola inwestycji w zasoby ludzkie $w$ działalności innowacyjnej firm usługowych}

Źródłem informacji o inwestycjach w zasoby ludzkie w przedsiębiorstwach usługowych i przemysłowych są wyniki badania CIS w obszarze „Działalność innowacyjna i wydatki na działalność innowacyjną". Niestety, nie można posłużyć się danymi na temat wydatków firm na szkolenia dla działalności innowacyjnej, bo mimo iż jest to jedna $\mathrm{z}$ form działalności innowacyjnej, wydatki w tym obszarze nie są uwzględnione w definicji wydatków na działalność innowacyjną. Wykorzystać można tu jedynie dane dotyczące odsetka firm deklarujących zaangażowanie w szkolenia dla działalności innowacyjnej na tle ich zaangażowania w pozostałe rodzaje działalności innowacyjnej (tab. 4).

Tabela 4. Odsetek przedsiębiorstw zaangażowanych w różne rodzaje działalności innowacyjnej w latach 2004 i 2010 w krajach objętych badaniem CIS

\begin{tabular}{|c|c|c|c|c|c|c|c|c|c|c|c|c|c|c|c|}
\hline \multirow{2}{*}{ Wyszczególnienie } & \multirow{2}{*}{ Rok } & \multicolumn{2}{|c|}{$\mathrm{Sz}$} & \multicolumn{2}{|c|}{ WB\&R } & \multicolumn{2}{|c|}{ ZB\&R } & \multicolumn{2}{|c|}{ MSO } & \multicolumn{2}{|c|}{ ZW } & \multicolumn{2}{|c|}{ WnR } & \multicolumn{2}{|c|}{ Inne } \\
\hline & & $\mathrm{U}$ & $\mathrm{P}$ & $\mathrm{U}$ & $\mathrm{P}$ & $\mathrm{U}$ & $\mathrm{P}$ & $\mathrm{U}$ & $\mathrm{P}$ & $\mathrm{U}$ & $\mathrm{P}$ & $\mathrm{U}$ & $\mathrm{P}$ & $\mathrm{U}$ & $\mathrm{P}$ \\
\hline 1 & 2 & 3 & 4 & 5 & 6 & 7 & 8 & 9 & 10 & 11 & 12 & 13 & 14 & 15 & 16 \\
\hline \multirow[t]{2}{*}{ Belgia } & 2004 & 63 & 62 & 46 & 61 & 23 & 31 & 70 & 78 & 23 & 16 & 39 & 38 & 32 & 33 \\
\hline & 2010 & 59 & 61 & 45 & 69 & 30 & 34 & 53 & 70 & 21 & 21 & 36 & 36 & 28 & 34 \\
\hline \multirow[t]{2}{*}{ Bułgaria } & 2004 & 39 & 28 & 9 & 9 & 18 & 10 & 55 & 70 & 38 & 19 & 39 & 27 & 40 & 37 \\
\hline & 2010 & 45 & 29 & 22 & 13 & 15 & 7 & 63 & 66 & 27 & 15 & 43 & 23 & 33 & 28 \\
\hline \multirow[t]{2}{*}{ Czechy } & 2004 & 52 & 39 & 41 & 50 & 26 & 21 & 75 & 77 & 32 & 21 & 49 & 47 & 38 & 44 \\
\hline & 2010 & 53 & 44 & 55 & 60 & 32 & 29 & 78 & 78 & 33 & 22 & - & 41 & 38 & 47 \\
\hline \multirow[t]{2}{*}{ Dania } & 2004 & 59 & 54 & 31 & 48 & 19 & 29 & 54 & 69 & 38 & 33 & 46 & 45 & 64 & 70 \\
\hline & 2010 & 32 & 27 & - & - & 19 & 20 & 47 & 53 & 42 & 41 & - & - & - & - \\
\hline \multirow[t]{2}{*}{ Niemcy* } & 2004 & 60 & 53 & 42 & 63 & 15 & 26 & 78 & 75 & 24 & 23 & 26 & 41 & 49 & 63 \\
\hline & 2010 & - & - & 39 & 56 & 12 & 21 & - & - & - & - & - & - & - & - \\
\hline \multirow[t]{2}{*}{ Estonia* } & 2004 & 59 & 58 & 42 & 44 & 23 & 23 & 58 & 87 & 39 & 33 & 45 & 38 & 52 & 48 \\
\hline & 2010 & 56 & 50 & 54 & 51 & 30 & 29 & 83 & 88 & 55 & 43 & 42 & 31 & 78 & 81 \\
\hline \multirow[t]{2}{*}{ Irlandia* } & 2004 & - & - & 86 & 85 & 16 & 27 & 93 & 82 & 14 & 31 & - & - & - & - \\
\hline & 2010 & - & - & 37 & 56 & 17 & 26 & 47 & 54 & 12 & 15 & - & - & - & - \\
\hline Grecja* & 2004 & 78 & 68 & 53 & 48 & 38 & 27 & 67 & 91 & 18 & 12 & - & - & 30 & 22 \\
\hline \multirow[t]{2}{*}{ Hiszpania } & 2004 & 39 & 38 & 20 & 39 & 14 & 21 & 70 & 66 & 14 & 11 & 26 & 31 & 16 & 29 \\
\hline & 2010 & 37 & 15 & 20 & 37 & 15 & 21 & 36 & 30 & 2 & 2 & 12 & 20 & 5 & 8 \\
\hline \multirow[t]{2}{*}{ Francja } & 2004 & 63 & 54 & 57 & 76 & 19 & 30 & 58 & 61 & 28 & 21 & 34 & 35 & 23 & 30 \\
\hline & 2010 & 64 & 58 & 58 & 72 & 29 & 34 & 54 & 61 & 33 & 29 & 38 & 35 & 45 & 44 \\
\hline \multirow[t]{2}{*}{ Włochy } & 2004 & 48 & 45 & 43 & 62 & 17 & 21 & 90 & 91 & 25 & 17 & 22 & 25 & 14 & 35 \\
\hline & 2010 & 38 & 30 & 32 & 50 & 15 & 18 & 85 & 84 & 16 & 12 & 32 & 28 & 12 & 9 \\
\hline
\end{tabular}




\begin{tabular}{|c|c|c|c|c|c|c|c|c|c|c|c|c|c|c|c|}
\hline 1 & 2 & 3 & 4 & 5 & 6 & 7 & 8 & 9 & 10 & 11 & 12 & 13 & 14 & 15 & 16 \\
\hline \multirow[t]{2}{*}{ Cypr } & 2004 & 93 & 84 & 17 & 29 & 19 & 13 & 99 & 97 & 41 & 29 & 31 & 29 & 51 & 57 \\
\hline & 2010 & 90 & 91 & 44 & 40 & 49 & 31 & 100 & 99 & 66 & 63 & 62 & 52 & 88 & 94 \\
\hline Łotwa & 2010 & 38 & 34 & 30 & 36 & 17 & 20 & 47 & 56 & 31 & 30 & 35 & 38 & 26 & 31 \\
\hline \multirow[t]{2}{*}{ Litwa } & 2004 & 56 & 52 & 28 & 30 & 20 & 14 & 81 & 90 & 27 & 27 & 44 & 47 & 26 & 19 \\
\hline & 2010 & 69 & 51 & 53 & 55 & 44 & 39 & 77 & 66 & 49 & 36 & 57 & 36 & 49 & 26 \\
\hline \multirow[t]{2}{*}{ Luksemburg } & 2004 & 80 & 76 & 42 & 55 & 26 & 23 & 75 & 78 & 24 & 24 & 58 & 52 & 38 & 40 \\
\hline & 2010 & 66 & 74 & - & 56 & 27 & 31 & 61 & 68 & 23 & 25 & 52 & 51 & 24 & 40 \\
\hline \multirow[t]{2}{*}{ Węgry } & 2004 & 54 & 46 & 40 & 45 & 21 & 14 & 79 & 73 & 21 & 15 & 35 & 35 & 24 & 31 \\
\hline & 2010 & 43 & 34 & 43 & 50 & 25 & 27 & 67 & 65 & 23 & 20 & 29 & 23 & 41 & 38 \\
\hline Malta & 2004 & 39 & 33 & 26 & 49 & 5 & 12 & 45 & 53 & 13 & 14 & 40 & 28 & 27 & 31 \\
\hline Malta & 2010 & 34 & 39 & 13 & 52 & 1 & 3 & 36 & 46 & 11 & 10 & 25 & 30 & 23 & 32 \\
\hline \multirow[t]{2}{*}{ Holandia } & 2004 & 46 & 48 & 63 & 71 & 30 & 40 & 59 & 69 & 26 & 24 & 37 & 35 & 27 & 26 \\
\hline & 2010 & 38 & 38 & 40 & 68 & 18 & 27 & 50 & 56 & 18 & 16 & 23 & 25 & 18 & 24 \\
\hline Austria* & 2010 & 58 & 61 & 39 & 62 & 23 & 34 & 54 & 71 & 36 & 33 & 46 & 47 & 44 & 51 \\
\hline \multirow[t]{2}{*}{ Polska } & 2004 & 34 & 14 & 22 & 31 & 11 & 10 & 99 & 85 & 12 & 5 & 20 & 15 & 11 & 10 \\
\hline & 2010 & 62 & 52 & 25 & 34 & 20 & 21 & 77 & 78 & 23 & 20 & 40 & 34 & 42 & 43 \\
\hline \multirow[t]{2}{*}{ Portugalia } & 2004 & 77 & 60 & 47 & 43 & 34 & 25 & 84 & 87 & 28 & 24 & 46 & 35 & 40 & 34 \\
\hline & 2010 & 64 & 52 & 46 & 41 & 28 & 19 & 70 & 66 & 17 & 12 & 30 & 24 & 32 & 34 \\
\hline \multirow[t]{2}{*}{ Rumunia } & 2004 & 61 & 59 & 28 & 30 & 13 & 9 & 76 & 80 & 13 & 13 & 42 & 31 & 32 & 29 \\
\hline & 2010 & 39 & 35 & 38 & 37 & 16 & 10 & 80 & 76 & 18 & 13 & 40 & 37 & 24 & 29 \\
\hline Słowenia & 2010 & 43 & 45 & 70 & 77 & 34 & 39 & 69 & 78 & 36 & 35 & 43 & 45 & 38 & 42 \\
\hline \multirow[t]{2}{*}{ Słowacja } & 2004 & 70 & 64 & 50 & 59 & 29 & 25 & 77 & 78 & 29 & 22 & 51 & 51 & 31 & 37 \\
\hline & 2010 & 66 & 58 & 47 & 51 & 29 & 26 & 66 & 75 & 22 & 18 & 64 & 53 & 40 & 57 \\
\hline Finlandia* & 2010 & 36 & 34 & 74 & 83 & 49 & 60 & 63 & 70 & 42 & 43 & 39 & 40 & 36 & 40 \\
\hline \multirow[t]{2}{*}{ Szwecja } & 2004 & 68 & 67 & 55 & 75 & 22 & 35 & 54 & 76 & 37 & 44 & 37 & 40 & 36 & 38 \\
\hline & 2010 & 23 & 25 & 55 & 67 & 25 & 34 & 69 & 82 & 50 & 57 & 37 & 33 & 23 & 23 \\
\hline
\end{tabular}

Sz - szkolenia; WB+R - wewnętrzne B+R; ZB+R - zewnętrzne B+R; MSO - maszyny, sprzęt, oprogramowania; ZW - zewnętrzna wiedza; WnR - wprowadzenie na rynek. P i U - jak w tab. 1. * Dane dla sektora usług stanowiących rdzeń działalności innowacyjnej.

Źródło: [Eurostat, Results of the fourth Community Innovation Survey (CIS4) [inn_cis4]; Innovation activity and expenditure in 2004, [inn_cis4_exp]; Results of the Community Innovation Survey 2010 [inn_cis7]; Innovation activities and expenditures in 2010, [inn_cis7_exp]].

W większości krajów w całym analizowanym okresie odsetek przedsiębiorstw zaangażowanych w szkolenia dla działalności innowacyjnej wyższy był w grupie firm usługowych niż przemysłowych - różnice na ogół nie przekraczały 10 p.p., a największa różnica, wynosząca 22 p.p., miała miejsce w Hiszpanii w 2010 r. Natomiast w tych krajach, w których większe zaangażowanie deklarowały firmy przemysłowe różnice 
były niewielkie - na ogół na poziomie 1-2 p.p., choć w porównaniu z rokiem 2008 (CIS-6) podwoiła się liczba takich krajów. Należy jednak pamiętać, iż analizowane dane odnoszą się tylko do firm wprowadzających innowacje technologiczne, a przewaga przedsiębiorstw usługowych nad przemysłowymi w tym obszarze powinna być wyższa w grupie firm wprowadzających innowacje nietechnologiczne ${ }^{14}$.

W większości krajów miał miejsce spadek odsetka firm zarówno usługowych, jak i przemysłowych, zaangażowanych w tę formę działalności innowacyjnej. Do wyjątków należały firmy polskie, które w $2010 \mathrm{r}$. znacząco zwiększyły swoje zaangażowanie w szkolenia dla działalności innowacyjnej (w firmach usługowych prawie 2-krotny wzrost odsetka, a w firmach przemysłowych - 4-krotny), choć w 2004 r., w porównaniu z innymi krajami, notowały one niskie wartości tego wskaźnika. Odsetek firm deklarujących zaangażowanie w szkolenia dla działalności innowacyjnej na ogół plasował się na drugim miejscu (w 2004 r. w 5, a w 2010 r. w 6 krajach na pierwszym miejscu), za zakupem maszyn, sprzętu i oprogramowania, a przed wewnętrznymi $B+R$ lub wprowadzeniem innowacji na rynek. W firmach przemysłowych też największy odsetek firm deklarował zaangażowanie w zakup maszyn, sprzętu i oprogramowania (na ogół większy odsetek niż w usługach), a dalej - w wewnętrzne B+R i szkolenia dla działalności innowacyjnej.

Dane dotyczące wydatków na szkolenia dla działalności innowacyjnej dla Polski pokazują, iż udział tych wydatków w całkowitych wydatkach był 2-krotnie wyższy w firmach usługowych niż w przemysłowych, a w obydwu sektorach kształtował się na najniższym poziomie (usługi: wartość $82,6 \mathrm{mln}$ zł, udział w całkowitych wydatkach - 0,8\%; przemysł - odpowiednio: $105,7 \mathrm{mln}$ zł i 0,4\%).

\subsection{Nietechnologiczny charakter innowacji, w tym istotna rola innowacji organizacyjnych w firmach usługowych}

Możliwość weryfikacji tezy o kluczowej roli innowacji nietechnologicznych w firmach usługowych pojawiła się dopiero wraz z wprowadzeniem rozszerzonej definicji innowacji, obejmującej, obok innowacji technologicznych, również innowacje nietechnologiczne. Po raz pierwszy zastosowano ją w badaniu CIS-6 (2008 r.), ale w tab. 5 przedstawiono wyniki badania CIS-7 $(2010 \text { r. })^{15}$.

Dane zawarte w tab. 5 (kolumny 2-7) pokazują, iż odsetek firm, które wprowadziły tylko innowacje technologiczne, wyższy był w firmach przemysłowych (w większości krajów o ok. 10 p.p.), a odsetek firm, które wprowadziły tylko innowacje nietechnologiczne, w firmach usługowych (średnio o ok. 10-20 p.p.). Ponadto w 2010 r.

${ }^{14}$ Ze względu na to, iż innowacje nietechnologiczne zawarte są przede wszystkim w kompetencjach, głównie usługodawcy, ale często też usługobiorcy.

${ }^{15} \mathrm{~W}$ badaniu CIS-7 odsetek firm, które wprowadziły tylko innowacje technologiczne, tylko innowacje nietechnologiczne oraz jednocześnie technologiczne i nietechnologiczne, daje w sumie 100. Natomiast w badaniu CIS-6 zsumowanie tych wartości na ogół nie daje wartości 100, co wskazuje na niekompletność tych danych. 
w większości analizowanych krajów (18) odsetek firm usługowych, które wprowadziły tylko innowacje nietechnologiczne, przewyższał odsetek firm przemysłowych, które wprowadziły tylko innowacje technologiczne, a w wielu krajach różnica była znacząca (10-20 p.p.).

Jeśli chodzi o wskazywane w literaturze przedmiotu, kluczowe znaczenie innowacji organizacyjnych w sektorze usługowym, to do zbadania tej kwestii wykorzystać można wyniki badania CIS-6 i CIS-7 w obszarze „Innowacje organizacyjne i marketingowe". W 2008 r. (CIS-6) w większości krajów odsetek firm wprowadzających innowacje organizacyjne wyższy był w firmach przemysłowych niż usługowych. Sytuacja odwrotna miała miejsce w 8 krajach, w tym w Polsce i w większości krajów, jeśli punktem odniesienia był sektor usług stanowiących rdzeń działalności innowacyjnej, choć nie widać istotnej przewagi firm usługowych nad firmami przemysłowymi w zakresie wprowadzania innowacji organizacyjnych.

Tabela 5. Odsetek firm z działalnością innowacyjną według typu innowacji w 2010 r. oraz odsetek firm, które w latach 2008-2010 wprowadziły innowacje organizacyjne i/lub marketingowe, jako procent wszystkich przedsiębiorstw biorących udział w badaniu CIS

\begin{tabular}{|l|c|c|c|c|c|c|c|c|c|c|}
\hline \multirow{2}{*}{ Wyszczególnienie } & \multicolumn{9}{|c|}{$\begin{array}{c}\text { Odsetek firm z działalnością innowacyjną } \\
\text { według typu innowacji }\end{array}$} & \multicolumn{3}{c|}{$\begin{array}{c}\text { Odsetek firm, które } \\
\text { wprowadziły innowacje: }\end{array}$} \\
\cline { 2 - 15 } & \multicolumn{2}{|c|}{ tylko T } & \multicolumn{2}{c|}{ tylko NT } & \multicolumn{2}{c|}{ T\&NT } & \multicolumn{2}{c|}{ O* } & \multicolumn{2}{c|}{ M $^{*}$} \\
\cline { 2 - 15 } & $\mathrm{P}$ & $\mathrm{U}$ & $\mathrm{P}$ & $\mathrm{U}$ & $\mathrm{P}$ & $\mathrm{U}$ & $\mathrm{P}$ & $\mathrm{U}$ & $\mathrm{P}$ & $\mathrm{U}$ \\
\hline \multirow{2}{*}{1} & 2 & 3 & 4 & 5 & 6 & 7 & 8 & 9 & 10 & 11 \\
\hline UE (27) & - & - & - & - & - & - & 30 & 32 & 26 & 27 \\
\hline Belgia & 33 & 27 & 14 & 16 & 54 & 57 & 31 & 31 & 31 & 27 \\
\hline Bułgaria & 43 & 24 & 28 & 45 & 29 & 31 & 12 & 13 & 13 & 12 \\
\hline Czechy & 21 & 14 & 28 & 40 & 51 & 46 & 30 & 32 & 29 & 30 \\
\hline Dania & 24 & 16 & 18 & 28 & 58 & 56 & 36 & 33 & 27 & 28 \\
\hline Niemcy & 24 & 20 & 14 & 24 & 62 & 55 & 46 & 47 & 47 & 45 \\
\hline Estonia & 40 & 30 & 13 & 24 & 48 & 46 & 22 & 26 & 25 & 27 \\
\hline Irlandia & 28 & 18 & 14 & 26 & 58 & 55 & 37 & 36 & 30 & 31 \\
\hline Hiszpania & 36 & 24 & 23 & 43 & 41 & 33 & 23 & 21 & 15 & 13 \\
\hline Francja & 23 & 11 & 28 & 47 & 49 & 42 & 36 & 37 & 23 & 28 \\
\hline Włochy & 26 & 14 & 23 & 46 & 52 & 40 & 31 & 31 & 28 & 29 \\
\hline Cypr & 25 & 11 & 19 & 25 & 57 & 64 & 30 & 33 & 24 & 32 \\
\hline Lotwa & 28 & 16 & 39 & 49 & 33 & 36 & 18 & 18 & 12 & 16 \\
\hline Litwa & 27 & 13 & 30 & 38 & 44 & 49 & 17 & 24 & 16 & 26 \\
\hline Luksemburg & 18 & 10 & 20 & 28 & 62 & 62 & 45 & 53 & 33 & 41 \\
\hline Węgry & 26 & 22 & 38 & 44 & 36 & 34 & 13 & 15 & 16 & 19 \\
\hline Malta & 29 & 13 & 15 & 45 & 56 & 43 & 26 & 24 & 20 & 21 \\
\hline
\end{tabular}


Tabela 5, cd.

\begin{tabular}{|l|c|c|c|c|c|c|c|c|c|c|}
\hline \multicolumn{1}{|c|}{1} & 2 & 3 & 4 & 5 & 6 & 7 & 8 & 9 & 10 & 11 \\
\hline Holandia & 37 & 31 & 12 & 25 & 51 & 44 & 31 & 23 & 22 & 22 \\
\hline Austria & 27 & 18 & 17 & 27 & 56 & 55 & 34 & 33 & 28 & 28 \\
\hline Polska & 29 & 18 & 36 & 52 & 36 & 30 & 13 & 15 & 14 & 16 \\
\hline Portugalia & 24 & 16 & 22 & 25 & 54 & 59 & 30 & 44 & 30 & 40 \\
\hline Rumunia & 17 & 11 & 46 & 62 & 37 & 27 & 17 & 20 & 18 & 20 \\
\hline Słowenia & 22 & 13 & 29 & 41 & 53 & 47 & 30 & 25 & 28 & 29 \\
\hline Słowacja & 23 & 11 & 16 & 28 & 61 & 61 & 22 & 22 & 18 & 22 \\
\hline Finlandia & 33 & 24 & 12 & 23 & 55 & 54 & 31 & 32 & 27 & 28 \\
\hline Szwecja & 32 & 25 & 16 & 21 & 53 & 55 & 27 & 29 & 29 & 34 \\
\hline W. Brytania & - & - & - & - & - & - & 33 & 29 & 17 & 19 \\
\hline
\end{tabular}

$\mathrm{T}$ - technologiczne; NT - nietechnologiczne; O - organizacyjne; M - marketingowe. UE (27), Niemcy, Estonia, Irlandia, Luksemburg, Austria, Finlandia, W. Brytania - dane dla sektora usług stanowiących rdzeń działalności innowacyjnej. Słowenia - dane za 2008 r. * Odsetek firm, które wprowadziły innowacje organizacyjne, obejmuje wszystkie firmy, które wprowadziły: tylko innowacje organizacyjne lub w połączeniu z innymi innowacjami. To samo dotyczy innowacji marketingowych. P i U - jak w tab. 1.

Źródło: [Eurostat, Results of the community innovation survey 2010 [inn_cis7], kolumny 2-7: Enterprises by type of innovation activity [inn_cis7_type]; kolumny 8-1: Organisational and marketing innovation [inn_cis6_mo]].

W 2010 r. (CIS-7 - tab. 5, kolumny 8-11) sytuacja odwróciła się, ponieważ w większości krajów odsetek firm wprowadzających tego typu innowacje wyższy był w usługach, ale różnice pozostały nieznaczne (na ogół na poziomie ok. 1-3 p.p., tylko w kilku krajach mieściły w granicach 5-15 p.p.). Podobna sytuacja miała miejsce w firmach wprowadzających innowacje marketingowe oraz jednocześnie innowacje organizacyjne i marketingowe. Należy ponadto zauważyć, że zmiana na korzyść sektora usługowego może być też efektem poprawy jakości danych w tym obszarze.

Natomiast wyniki badania CIS-7 i CIS-6 pokazują, iż innowacje nietechnologiczne na ogół towarzyszą innowacjom technologicznym, jako że najwyższy odsetek firm, zarówno przemysłowych, jak i usługowych, wprowadził jednocześnie innowacje technologiczne i nietechnologiczne. Podobne wnioski wynikały z wcześniejszych badań prowadzonych na mniejszą skalę [Wyszkowska-Kuna 2012].

Odsetek firm, zarówno usługowych, jak i przemysłowych, wprowadzających innowacje organizacyjne kształtował się na podobnym poziomie jak odsetek firm wprowadzających innowacje marketingowe; w obydwu przypadkach był on niższy w części krajów nowo przyjętych do UE niż w krajach starej UE. 


\section{Zakończenie}

Na podstawie wyników badania CIS możliwa jest empiryczna weryfikacja dwóch cech uznawanych za kluczowe dla odróżnienia produktów/działalności usługowej od przemysłowej. Cechy te to interaktywność usług, która przekłada się na interaktywny charakter procesów innowacyjnych w firmach usługowych, oraz niematerialność usług, która przekłada się na trudności ze identyfikowaniem i mierzeniem innowacji o charakterze niematerialnym.

Jednakże należy zauważyć, iż wyniki badania CIS nie potwierdzają interaktywnego charakteru działalności innowacyjnej w firmach usługowych, ponieważ w większości krajów na współpracę z klientem, jako najbardziej wartościowym partnerem w procesie innowacyjnym, częściej wskazywały firmy przemysłowe niż usługowe. Konieczne wydają się tu zatem badania sektorowe, bo jak pokazują wcześniejsze badania, cecha ta może się odnosić tylko do niektórych usług.

Natomiast w przypadku drugiej cechy faktycznie można mówić o występowaniu trudności z oszacowaniem ekonomicznych efektów innowacji usługowych. Wskaźnikiem zalecanym tu przez Oslo Manual jest przychód ze sprzedaży produktów nowych lub istotnie ulepszonych, wprowadzonych na rynek w ciągu ostatnich trzech lat w wartości przychodów ogółem. Jak pokazują wyniki CIS, wskaźnik ten był dużo niższy w firmach usługowych niż w przemysłowych, a różnice w jego poziomie były znacznie większe niż przy porównywaniu odsetka innowacyjnych firm usługowych i przemysłowych. Dlatego też można przypuszczać, co potwierdzają też wcześniejsze badania, iż wskaźnik ten nie ujmuje w pełni ekonomicznych efektów innowacji usługowych. Natomiast nie sposób zweryfikować tezy o trudnościach z odróżnieniem różnych typów innowacji w usługach, ponieważ w kwestionariuszu CIS brakuje pytań na ten temat.

Jeśli chodzi o pozostałe cechy charakteryzujące działalność innowacyjną w firmach usługowych, to potwierdzona została kluczowa rola ICT w działalności innowacyjnej firm usługowych. Co prawda, nie ma zbiorczych danych na temat wydatków na zakup oprogramowania w krajach UE, ale dane dla Polski pokazują, iż w minionej dekadzie w firmach usługowych udział tych wydatków w całkowitych wydatkach na działalność innowacyjną notował 4-krotny wzrost, wysuwając się na drugie miejsce i osiągając 8-krotnie wyższą wartość niż w fïmach przemysłowych. Również dane dotyczące aktywów trwałych w przedsiębiorstwach, dostępne dla kilku krajów UE, pokazują, iż w firmach usługowych udział aktywów niematerialnych był średnio ok. 2-, 3-krotnie wyższy niż w przemysłowych, w tym udział oprogramowania był średnio ok. 2-krotnie wyższy.

Niestety nie można w pełni potwierdzić kluczowej roli inwestycji w zasoby ludzkie ze względu na brak danych w badaniu CIS na temat wydatków firm na szkolenia dla działalności innowacyjnej w krajach UE. Dane takie dostępne są dla Polski i mimo iż w firmach usługowych były one 2-krotnie wyższe niż w firmach przemysłowych, w obydwu sektorach plasowały się na najniższym poziomie. Dla krajów UE dostępne 
są natomiast dane pokazujące odsetek firm zaangażowanych w tę formę aktywności innowacyjnej; w usługach odsetek ten plasował się na drugim miejscu i był na ogół wyższy niż w przemyśle.

Ciekawe wnioski wynikają również z weryfikacji tezy o nietechnologicznym charakterze innowacji w usługach. Co prawda, odsetek firm, które wprowadziły tylko innowacje nietechnologiczne, wyższy był w firmach usługowych, a odsetek firm, które wprowadziły tylko innowacje technologiczne - w firmach przemysłowych, co jest zgodne z tezą o nietechnologicznym charakterze innowacji w usługach. Jednakże odsetek firm wprowadzających innowacje organizacyjne wyższy był w firmach przemysłowych niż w firmach usługowych (różnice raczej nieznaczne), co nie potwierdza kluczowego znaczenia zmian organizacyjnych w firmach usługowych. Okazuje się, iż zmiany organizacyjne są nie mniej ważne również w firmach przemysłowych. Jednocześnie wyniki badania CIS pokazują, iż innowacje nietechnologiczne na ogół towarzyszą innowacjom technologicznym, gdyż najwyższy był odsetek firm, które wprowadziły obydwa rodzaje innowacji jednocześnie ${ }^{16}$. Widać zatem, iż nie można dokonać prostego rozróżnienia na innowacje nietechnologiczne w firmach usługowych i innowacje technologiczne w firmach przemysłowych. Wydaje się, iż może to stanowić uzasadnienie dla rozwoju podejścia integracyjnego w badaniach nad innowacjami, bez podziału na oddzielne badania nad innowacjami w usługach i w przemyśle.

Reasumując, można powiedzieć, iż dane empiryczne z badań CIS na ogół potwierdzają cechy charakteryzujące działalność innowacyjną i innowacje w firmach usługowych, mimo iż w większości przypadków odnosiły się one tylko do firm wprowadzających innowacje technologiczne. Dlatego też można przypuszczać, iż pozytywna weryfikacja tych cech powinna być silniejsza, gdyby w badaniu CIS uwzględniono firmy z innowacjami tylko nietechnologicznymi, jako że występują one częściej właśnie w firmach usługowych. Podkreślić należy także konieczność objęcia kolejnym badaniem CIS wszystkich firm, również tych wprowadzających tylko innowacje nietechnologiczne, szczególnie że - jak pokazują dane przedstawione w artykule - innowacje nietechnologiczne są nie mniej ważne od innowacji technologicznych, i to w firmach z obydwu sektorów. Ponadto poprawiłoby to jakość większości danych dotyczących działalności innowacyjnej w firmach usługowych.

Wskazać należy też inne zmiany, które powinny przyczynić się poprawy jakości danych w obszarze działalności innowacyjnej w firmach usługowych, tj.:

- Wprowadzenie do kwestionariusza badania CIS pytania o trudności z odróżnieniem przez firmy innowacji produktowych od procesowych oraz organizacyjnych od procesowych.

- Wprowadzenie do kwestionariusza badania CIS takich pytań, które pozwoliłyby firmom zidentyfikować innowacje typu „ciągła zmiana”.

${ }^{16}$ Podobne wnioski wynikały z wcześniejszych badań prowadzonych na znacznie mniejszą skalę [Wyszkowska-Kuna 2012]. 
- Wyodrębnienie w wydatkach na działalność innowacyjną wydatków na zakup oprogramowania oraz uwzględnienie kategorii wydatków na szkolenia dla działalności innowacyjnej.

\section{Literatura}

Antonelli C., 1998, Localized technological change, new information technology and the knowledge-based economy: The European evidence, "Journal of Evolutionary Economics", no. 8, s. 177-198.

Antonelli C., 1999, The evolution of the industrial organization of the production of knowledge, "Cambridge Journal of Economics", vol. 23, s. 243-260.

Arundel A., Kanerva M., van Cruysen A., Hollanders H., 2007, Innovation Statistics for the European Service Sector, UNU-MERIT, INNO-Metrics Thematic Papers.

Bloch C., 2007, Service Innovation in the Nordic Countries: An Analysis Using CIS4 Data, Nordic Innovation Centre.

Camacho J.A., Rodriguez M., 2005, How innovative are services? An empirical analysis for Spain, "The Service Industries Journal", vol. 25, no. 2, s. 253-271.

Ducatel K., Miles I., 1994, The Diffusion of Information Technology in Europe, [w:] Employment and Technical Change in Europe, ed. K. Ducatel, Aldershot, Edward Elgar.

Eurostat, 2011, Science, Technology and Innovation in Europe, Pocketbooks.

Eurostat, 2008, The Community Innovation Survey 2008, The Harmonised Survey Questionnaire.

Eurostat, Annual national accounts, National accounts detailed breakdown, Gross fixed capital formation, Database, Cross-classification of fixed assets by industry and by non-financial fixed assets and balance sheets for non-financial assets [nama t ]; Cross-classification of fixed assets by industry and by non-financial fixed asset - current prices [nama_t20_21_c] (26.11.2012).

Eurostat, Results of the fourth Community Innovation Survey (CIS4) (inn_cis4), http://epp.eurostat. ec.europa.eu/portal/page/portal/statistics: Innovation Co-Operation During 2002-2004 (inn_cis4_ coop); Innovation activity and expenditure in 2004 (inn_cis4_exp).

Eurostat, Results of the Community Innovation Survey 2010 (CIS2010) (inn_cis7), http://epp.eurostat. ec.europa.eu/portal/page/portal/statistics/themes (30.01.2013): Enterprises by type of innovation activity [inn_cis7_type]; Innovation activities and expenditures in 2010 (inn_cis7_exp); Types of co-operation partner for product and process innovation [inn_cis7_coop]; Organisational and marketing innovation [inn_cis7_mo].

Eurostat, Turnover from Innovation as Percentage of Total Turnover, http://, http://epp.eurostat.ec.europa.eu/portal/page/portal/statistics.

Flikkema M., Jansen P., van der Sluis L., 2007, Identifying Neo-Schumpeterian innovation in service firms: A conceptual essay with a novel classification, "Economics of Innovation and New Technology", vol. 16(7).

Gago D., Rubalcaba L., 2007, Innovation and ICT in service firms: Towards a multidimensional approach for impact assessment, "Journal of Evolutionary Economics", vol. 17, s. 25-44.

Gallouj F., 2002a, Innovation in services and the attendant old and new myths, "Journal of Socio-Economics", vol. 31.

Gallouj F., 2002b, Innovation in the Service Economy: The New Wealth of Nations, Edward Elgar, Cheltenham, Northampton.

Gallouj F., Weinstein O., 1997, Innovation in services, "Research Policy", vol. 26, s. 537-556.

Gotsch M., Hipp C., Gallego J., Rubalcaba L., 2010, Sectoral Innovation Performance in the Knowledge Intensive Business Services, final report, Innova, Sector Innovation Watch.

GUS, Urząd Statystyczny w Szczecinie, 2010, Działalność innowacyjna przedsiębiorstw w latach 2006-2009 (2010), Informacje i Opracowania Statystyczne, Warszawa. 
GUS, Urząd Statystyczny w Szczecinie, 2012, Działalność innowacyjna przedsiębiorstw w latach 2008-2010, Informacje i Opracowania Statystyczne, Warszawa, http://www.stat.gov.pl/gus/nauka_technika_PLK_HTML.htm.

Hackett G.P., 1990, Investments in technology: The service sector sinkhole?, "MIT Sloan Management Review", vol. 31, issue 2.

Hill P., 1999, Tangibles, intangibles and services: A new taxonomy for the classification of output, "Canadian Journal of Economics", vol. 32, no. 2.

Hipp Ch., Tether B.S., Miles I., 2000, The incidence and effects of innovation in services: Evidence from Germany, "International Journal of Innovation Management", vol. 4, no. 4, s. 417-453.

Hipp Ch., Grupp H., 2005, Innovation in the service sector: The demand for service-specific innovation measurement concepts and typologies, "Research Policy", vol. 34, s. 517-535.

Howells J., 2000, Innovation and Services: New Conceptual Frameworks, CRIC Discussion Paper, 2000, no. 38, The University of Manchester.

Howells J., 2010, Services and innovation and service innovation, [w:] The Handbook of Innovation and Services, eds. F. Gallouj, F. Djellal, C. Gallouj, Edward Elgar, Cheltenham.

Leiponen A., 2006, Organization of knowledge exchange: An empirical study of knowledge intensive business service relationship, "Economics of Innovation and New Technology", vol. 15, s. 443$-463$.

Lundvall B.A., 2000, From the economics of knowledge to the learning economy, [w:] Knowledge Management in the Learning Economy, OECD, Paris.

Miles I., 2011, Innovation and the service economy, [w:] Innovation. Perspectives for the $21^{\text {st }}$ century, eds. F. Moss, T. E. Machover, BBVA Foundation, Madrid.

Miles I., 2010, Service innovation, [w:] Handbook of Service Science, eds. P.P. Maglio, Ch.A. Kieliszewski, J.C. Spohrer, Springer, s. 511-533.

Miles I., 2000, Services innovation: Coming of age in the knowledge-based economy, International "Journal of Innovation Management", no. 4, vol. 4, s. 371-389.

Miles I., Kastrinos N., Flanagan K., Bilderbeek R., den Hertog P., Huntink W., Bouman M., 1995, Knowledge-Intensive Business Services - Users, Carriers and Sources of Innovation, The University of Manchester, Manchester, https://research.mbs.ac.uk/INNOVATION/Portals/0/docs/KIBSEIMS1995shortreport.pdf.

OECD/Eurostat, 1997, The Measurement of Scientific and Technological Activities Proposed Guidelines For Collecting And Interpreting Technological Innovation Data, Oslo Manual, Paris.

OECD, 1992, OECD Proposed Guidelines for Collecting and Interpreting Technological Innovation Data: Oslo Manual, Paris.

OECD/Eurostat, 2005, The measurement of Scientific and Technological Activities Proposed Guidelines for Collecting and Interpreting Technological Innovation Data, Oslo Manual, Paris.

Oliveira P., von Hippel E., 2011, Users as service innovators: The case of banking industry, "Research Policy", vol. 40, s. 806-818.

Porrino F., 2012, Technologie informacyjno-komunikacyjne, Parlament Europejski, http://www.europarl.europa.eu/ftu/pdf/pl/FTU_4.8.3.pdf.

Preiss1 B., 2000, Service innovation: What makes it different? Empirical evidence from Germany, [w:] Innovation Systems in the Service Economy, Measurement and Case Study Analysis, eds. J.S. Metcalfe, I. Miles, Kluwer Academic Publishers, Boston, Dordrecht, London.

Quinn J.B., Paquette P.C., 1990, Technology in services: Creating organisational revolutions, "Sloan Management Review", vol. 11 (2), s. 67-78.

Scarbrough H., Lannon R., 1989, The Management of innovation in the financial services sector: A case study, "Journal of Marketing Management", vol. 5, no. 1, s. 51-62.

Sirilli G., Evangelista R., 1998, Technological innovation in services and manufacturing: Results from Italian surveys, "Research Policy", vol. 27. 
Sundbo J., 1997, Management of innovation in services, "The Service Industries Journal”, vol. 17, no. 3. Tether B.S., 2004, Do services innovate (differently)?, "CRIC Discussion Paper", no. 66, Centre for Research on Innovation and Competition, The University of Manchester.

Tether B.S., 2005, Do services innovate (differently)? Insights from the European Innobarometer Survey, "Industry and Innovation," vol. 12, no. 2.

Tether B.S., 2001, Identifying Innovation, Innovators and Innovative Behaviour: A Critical Assessment of the Community Innovation Survey (CIS), CRIC Discussion Paper, no. 48, Centre for Research on Innovation and Competition, The University of Manchester.

Tether B.S., 2002, Who co-operates for innovation, and why: An empirical analysis, "Research Policy", vol. 31(6), s. 947-967.

Tether B.S., Hipp Ch., Miles I., 2001, Standarisation and particularisation in services: evidence from Germany, "Research Policy", vol. 30, issue 7, s. 1115-1138.

Tether B., Miles I., Blind K., Hipp Ch., de Liso N., Cainelli G., 2002, Innovation in the Service Sector. Analysis of data collected under the Community Innovation Survey (CIS-2), CRIC Working Paper No 11, ESRC Centre for Research on Innovation and Competition, The University of Manchester, Manchester.

Von Hippel E., 2005, Democratizing Innovation, the MIT Press, Cambridge-Massachussets, London, http://mitpress.mit.edu (7.03.2013).

Von Hippel E., 1988, The Sources of Innovation, Oxford University Press, http://web.mit.edu/evhippel/ www (7.03.2013).

Voss C., Johnston R, Silvestro R., Fitzgerald L., Brignall T., 1992, Measurement of innovation and design performance in services, "Design Management Journal", s. 40-60.

Wolfe R.A., 1994, Organizational innovation: Review, critique and suggested research directions, "Journal of Management Studies", vol. 31, no. 3, s. 405-431.

Wydro K.B., Kotowski Z., 1998, Technologie informacyjne a tendencje rozwojowe UE, [w:] Polska wobec wyzwań społeczeństwa informacyjnego: aksjologiczne i społeczne dylematy integracji z Unia Europejska, Raporty IRiSS, nr 67.

Wyszkowska-Kuna J., 2012, Znaczenie innowacji nietechnologicznych dla konkurencyjności gospodarki, Zeszyty Naukowe Uniwersytetu Ekonomicznego w Poznaniu. 